\title{
NICHE GLAGIERS IN BÜNSOW LAND, VESTSPITSBERGEN
}

\author{
By G. E. Groom \\ (Department of Geography, University College of Swansea)
}

\begin{abstract}
Small glaciers lying in funnel-shaped hollows on steep slopes have been variously described as wall-sided glaciers, cascade glaciers, cliff glaciers and niche glaciers. This type of glacier and the landforms associated with them in Bünsow Land, central Vestspitsbergen are described and their possible mode of origin is discussed. The theory that they were formed by an overspill of plateau ice and that they are thereby genetically related to hanging glaciers is rejected. It is suggested that they are formed by an accumulation of snow in an initially water-worn gully and that as the small glacier develops the original form of the gully is modified by nivation to a rounded, funnel-shaped hollow. Niche glaciers may thus be considered as glacier types genetically related to cirque glaciers, forming an early stage in corrie development.
\end{abstract}

Zusammenfassung. Kleine Gletscher, die in trichterförmigen Vertiefungen an steilen Abhängen liegen, sind verschiedentlich als ,wall-sided glaciers", ,cascade glaciers", ,cliff glaciers" und ,,Nischengletscher" beschrieben worden. Diese Art Gletscher und die damit verbundenen Bodengestalten in Bünsow Land, Vestspitsbergen werden beschrieben und ihre mögliche Entwicklungsweise wird besprochen. Die Theorie, dass sie durch Überlauf von Plateaueis gebildet wurden, und dass sie dadurch genetisch mit Hängegletschern zusammenhängen, wird abgelehnt. Es wird darauf hingedeutet, dass sie durch Anhäufung von Schnee in einer anfänglich durch Wasser erodierte Rinne gebildet wurden, und dass, wie sich nun der kleine Gletscher entwickelt, die ursprüngliche Form der Rinne durch Erosion von Firnflecken in eine abgerundete, trichterförmige Vertiefung verwandelt wird. Nischengletscher können daher als eine Gletscherart angesehen werden, die genetisch mit Kargletschern zusammenhängen und ein frühes Stadium in der Entwicklung der Kare bilden.

\section{INTRODUCTION}

Bünsow Land (Fig. I) is a small plateau area in central Vestspitsbergen consisting of unfolded rocks with a gentle dip of just over 2 degrees to the south. This plateau is deeply dissected by a rectangular valley pattern, and in places remnants of what is believed to be a summit erosional surface are preserved on broad interfluves. To-day the area is relatively ice-free in the south and south-west, but the ice cover increases to the north and east towards the central ice cap of Vestspitsbergen. The glacier types which remain are largely conformable to the relief. The plateau remnants support small ice caps and the valleys are occupied by various types of valley glacier, some of which result from the overflow of the main ice cap. Corrie glaciers are also present in the area. On the steep fjord and valley sides are found small ice masses which, even to-day after considerable ablation has caused many to disappear, are a distinctive feature of the landscape. It is the purpose of this paper to describe this type of glacier and the landforms associated with them.

\section{Previous Work}

In a paper in this fournal Dr. M. M. Sweeting and the present author ${ }^{\mathbf{1}}$ described the small glaciers which occur on many steep slopes in Bünsow Land as "slab" glaciers, and they incorrectly stated that Drygalski had named them Stufenvereisung. In a footnote to the same paper the editor of the Fournal drew attention to the confusion of terminology associated with this type of glacier.

Fig. 2. A characteristic niche glacier

Fig. 3. Niche glacier hollows on the north-western slopes of Campbellryggen. The central hollow occupied by a niche glacier is Type 2; the hollow to the right is Type 4 and the hollow on the left is Type 5 (see text)

Fig. 4. Niche glaciers and hollows on the southern slopes of Mathiesondaler. Type 3 may be seen on the slopes to the left; in the centre a typical Bünsow Land corrie has cut back into Skeltonfjellet and immediately to the right of this a well-developed niche glacier of Type $I$ illustrates the transitional form between a young niche glacier and a full corrie glacier 
Drygalski, ${ }^{2}$ in classifying the glaciers of Spitsbergen described two types which occur on valley sides. The Stufenvereisung (step glaciers) develop horizontally at the foot of valley-side steps, so forming lateral white stripes along the sides of bays and valleys. They commonly occur where lithological variations in nearly horizontal strata give rise to step-like variations

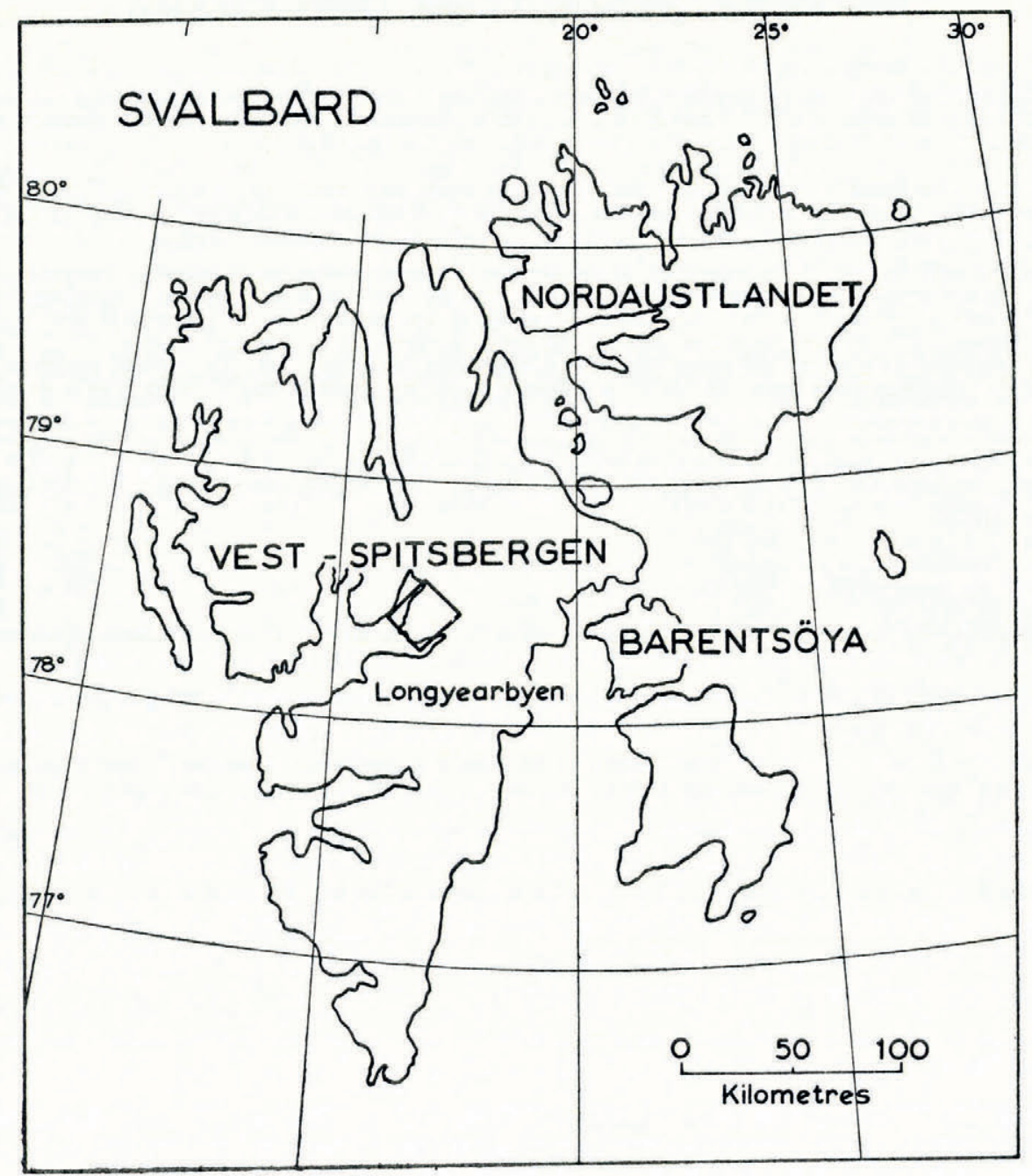

Fig. I. Map of Svalbard to show the location of Bünsow Land

in slope. Tyrell, ${ }^{3}$ in calling these cascade glaciers appears to have unwittingly initiated their confusion with more vertical ice masses which was followed by both Ahlmann ${ }^{4}$ and the present authors. The more vertical ice masses Drygalski grouped as Nischengletscher (niche glaciers). He pointed out the way in which these glaciers form in the niches of rock ridges which are commonly enlarged to a funnel-shape. His term Nischengletscher was also taken to include "all forms of ice which are situated in hollows of the valley sides, peaks and ridges". Stufen- 
vereisungen do not, as Tyrell stated, belong to this group of niche glaciers. Drygalski's classification was quite distinct.

\section{Features of Niche Glaciers}

Fig. 2, p. 368, shows the main features of a niche glacier as developed typically in Bünsow Land. The triangle of ice normally has a slightly convex surface profile and lies in a shallow funnel-shaped hollow developed on steep slopes with gradients up to $42^{\circ}$. A large number of these glaciers rest upon rock benches since the alternation of more resistant strata with less resistant strata is a characteristic feature of the geology of Bünsow Land.

From the toe of the glacier runs a short gully cut by melt water, and at the base of this is developed a typical dejection (debris) cone or fan. The gully is generally shallow and the steep nature of the slope makes the melt water flow almost a fall. Where the gully cuts through a more resistant rock bed that is maintaining, locally, a vertical slope, then the gully lies in a restricted narrow channel and opens out above and below the hard rock band. The cones maintain steep slopes and their upper limit extends well up the valley or cliff sides, but it was noticeable that where the volume of melt water was obviously greater (as from a larger glacier) the curve of the fan's gradient spread out much further laterally, provided that other processes were not actively removing the debris.

\section{Types of Niche Glacier Hollow}

During the present period of considerable ablation in Spitsbergen many niche glaciers are waning, and in places the ice has disappeared altogether leaving only the shallow funnelshaped hollow on the hillside as evidence of its former existence. The following main types of niche glacier hollows were observed in Bünsow Land (see Figs. 3 and 4, p. 368):

(1) Normal niche glaciers developed in funnel-shaped hollows with a slightly domed ice mass connected to the plateau ice cap above.

(2) Niche glaciers similar to (I) but in which the connexion with the plateau ice did not exist.

(3) Funnel-shaped hollows occupied by remnant strips of ice running either vertically or horizontally.

(4) Funnel-shaped hollows occupied only by seasonal horse-shoe-shaped or longitudinal snow patches, the latter being the "hour-glass" snow patch forms described by McCabe. ${ }^{5}$ W. V. Lewis ${ }^{6}$ also recognized such funnel-shaped hollows on the southern slopes of Snaefell in Iceland and described them as "embryo-cirques".

(5) Larger and more deeply incised funnel-shaped hollows in an advanced state of development. These larger depressions also show a variation of degree of ice occupance but are all characterized by the development of small moraine mounds above the melt water gully section.

\section{Development of Nighe Glaciers}

Drygalski's descriptive term, Nischengletscher, has no genetical implications and it is likely that some of the terminological confusion that has arisen around these glaciers is connected with the vague ideas about their origin and development.

Fundamentally their genesis could fall into one of two different categories, either: 
(a) They could have developed by the overflow of plateau ice and so be genetically related to the ice caps;

or

(b) They could have developed from the accumulation of snow on fjord and valley side slopes and so be genetically related to nivation and corrie glaciers.

The following discussion of these two hypotheses is based upon field observations made in Bünsow Land and also upon a study of the more important literature in which reference has been made to similar small ice masses.

\section{(a) Plateau Ice Overflow}

Wright and Priestley 7 introduced the term wall-sided glaciers to describe, "streams of ice originating in, and fed by, upland ice of any description, and flowing down towards sea level unconfined by any marked valley wall'". These could originate either by local advance of highland ice or by retreat of the highland ice. Any depressions occupied by these glaciers are regarded as unconnected with the erosive action of the ice. Wall-sided glaciers were recognized in Spitsbergen by Ahlmann ${ }^{8}$ but he did not make it clear whether these glaciers which he defines elsewhere 9 as "covering the side of a valley or some part of it" conformed to Wright and Priestley's definition. A. Hamberg ${ }^{\text {10 }}$ describing niche glaciers of northern Sweden regarded them as genetically related to hanging glaciers, from which at times, he found them difficult to differentiate.

On the basis of an overflow of plateau ice the development of niche glaciers could be reconstructed as follows:

(I) The growth of small plateau ice caps which move out radially to spill over the plateau edges.

(2) Great thicknesses of ice in the overspill avalanche down the slope leaving a thin ice tongue clinging to the steep slope and maintaining its connexion with the plateau ice.

(3) Melt water from both the plateau and overspill ice will gully the slope below the ice lobe and form a fan at its foot.

(4) With time nivation processes will hollow out the cliff beneath the ice tongue, and furthermore, differential weathering in a region of near horizontal strata will etch out small resistance differences in the rock strata. The more resistant bands will stand out as less weathered and steeper slope zones, whereas the less resistant bands will have less steep slopes upon which névé and ice will accumulate more readily. Where slopes are less steep the accumulated snow and ice patches will sap at the cliff behind and will enable the niche glacier ice to accumulate, quite apart from the plateau ice and so to develop a convex profile.

(5) If nivation continues and the niche glacier grows, the hollowing out of the slope will become more pronounced, and a small moraine will develop at the toe of the glacier when ice movement begins to take place.

(6) Development will diminish with, for example, increased ablation thinning the plateau ice. If this continues sufficiently far the glacier may become detached from its parent ice, in which case its subsequent life will be short unless it is able to maintain itself by direct precipitation.

(7) With the final melting of the niche glacier the mark of their occupance is left in funnelshaped hollows in the hillside, with gullies and fans below them. Melt water from seasonal snow accumulation in the hollows and also from the plateau may cause subsequent modification of the funnel shape and by erosion convert them to fluvial gully forms. 
It should be noted that the distinctive funnel shape of the hollows would be a function of the combined action of longitudinal erosion by snow, ice and melt water, with lateral widening from weathering along less resistant strata.

This hypothesis of plateau ice overflow makes the initiation of ice masses on slopes as steep as 42 degrees conceivable. Once an initial mass of ice is established it is suggested that processes associated with the niche glacier ice lead to the development of a hollow in the hillside. In this way these glaciers could not be considered true wall-sided glaciers in the sense of Wright and Priestley, but this difference could be due to the more active melt water processes in Bünsow Land.

In testing this hypothesis the niche glaciers of Bünsow Land were examined and it was seen that in many cases the upper margin of the niche glacier was connected to the plateau ice above. Where there was no such connexion, or where the connexion was along only part of the upper ice margin the niche glacier was waning and the impression gained was that the supply of ice had been largely cut off with severance from the ice cap. However, the serious objection to this hypothesis is that niche glaciers were observed on some slopes above which there was a ridge too narrow to support plateau ice. Thus, although some of these glaciers may originate from the overflow of plateau ice this is not likely to be a universal process.

\section{(b) Development of Snow-patches}

Alternative hypotheses for the development of niche glaciers may be based upon the accumulation of snow, but the problem involved here is whether sufficient snow could accumulate on slopes as steep as 42 degrees. R. D. Salisbury, an early worker in this field, described glaciers developed upon the face of cliffs in Greenland as cliff glaciers. "I His photographs show these to be the same as the Bünsow Land niche glaciers lying in similar funnelshaped hollows, and he suggests that they originated as snow drifts lodging against the cliff at the junction of the steep cliff face with the scree slope below. Salisbury also stated that there was no connexion between the top of the cliff glacier and the plateau ice. Salisbury made no mention of the processes that might be involved in the development or modification of the hollows in which the cliff glaciers lay as he was concerned primarily with the form of the glaciers.

The idea that erosion could take place beneath snow-patches was developed by W. V. Lewis in $1939 .^{12}$ The mechanism he invoked was the action of freeze and thaw and the removal of material from beneath the snow patches by water trickling underneath the snow, resulting in the formation of nivation hollows. Lewis considered that circular snow-patches gave rise to corries, but he also recognized longitudinal and transverse snow-patches. His longitudinal patches occupied hollows in the hillside which are very like the funnel-shaped hollows associated with the niche glaciers in Bünsow Land. Lewis did not account for the development of different shaped snow-patches, but a reasonable assumption is that the shape of initial niches in the hillside would be the controlling factor. The question then arises as to whether the longitudinal snow-patches are lying in funnel-shaped hollows which were initiated by niche glacier development following the overspill of the plateau ice; or whether the hollows were formed by niche glaciers which had developed from earlier snow-patches.

Following Lewis, L. H. McCabe ${ }^{13}$ studied snow-patches in Bünsow Land but his conclusions do nothing to resolve the problem of the origin of niche glaciers. He regarded the funnel-shaped hollows as incipient corries, "linking the original snow gullies with a fully matured corrie", and suggested that the longitudinal snow gullies were cut back above resistant bands of rock. The coalescence of several such gullies would then give rise to incipient corries in which banks of ice would accumulate to rest on the bench formed by more resistant strata, and so develop into small corrie glaciers. McCabe does not appear to recognize the development of the niche glacier either as a form distinct from the corrie glacier, or as an 
intermediate stage, neither does he make any observations concerning the initiation of the niche glacier hollows; nevertheless, these ideas can form the basis of a good working hypothesis for their formation.

\section{(c) Niche Glaciers and Hillside Gullies}

The very gentle dip of the rock bedding planes in Bünsow Land together with the marked lithological variations gives rise to structural benches and distinct changes of slope which run nearly horizontally along the sides of valleys and fjords. A free rock face is commonly exposed on the upper part of the slope, while scree accumulations of varying extents mantle the lower slopes. These features make the general aspect of the landscape very like tropical arid and semi-arid landscapes of similar structures. Like their tropical counterparts the upper valley slopes of Bünsow Land are notched by marked incisions or gullies. It is suggested here that the funnel-shaped hollows of Bünsow Land are developed from water-worn gullies.

Water-worn gullies in structurally controlled slopes are narrow and very steep-sided where they cut through resistant rock strata and widen out with less steep sides on the less resistant rocks. This gives rise to many ledges in restricted gully channels on which snow may accumulate, and a névé patch thus established will, as it develops to a glacier, bring about the rounding of the gully hollow by nivation processes. This hollow will be enlarged both by the growth of the glacier and also by the coalescence of adjacent hollows as they develop. Growth will also lead to the extension of the ice higher up the slope above the initial ledge, while continued nivation may cause the steepening of the upper parts of the slopes upon which the niche glacier lies. In this way the very steep slopes of some niche glaciers no longer present a problem which makes their initiation from snow-patch accumulation difficult as it is seen to be a secondary feature arising as the glacier cuts back into the hillside.

The resulting funnel-shaped hollow, if exposed by the melting of the glacier, becomes subject to incision by running water which usually derives from snow melt. Several such gullies may dissect a large hollow and may in their turn serve as sites for subsequent snow accumulation. In this way the initially large, well-developed niche glacier hollows may experience a second cycle of development.

While variation in lithology is necessary for the development of the breaks of slope on which niche glaciers originate, lithology also controls the shape of the hollow which subsequently develops. Weaker rocks give rise to open funnel-shaped hollows (Fig. 5a) and the slopes between neighbouring glaciers are not prominent. The upper slopes of the niche glacier hollow in this type of rock are usually greater than the slopes of the hillside into which the hollow is cut, and it is here that the advance of niche glacier development leads more quickly to the coalescence of neighbouring hollows. Strong rocks which support steep cliff faces give rise to steep-sided funnel-shaped hollows (Fig. 5 b). The nivation processes cut back more rapidly than the processes of weathering that attack the cliff face and so steep buttresses are maintained between neighbouring hollows. These buttresses have a gradient that is frequently greater than that of the rear wall of the hollows.

Niche glacier hollows therefore show variations in form which reflect both their development and the rock type, but despite this their form is quite distinctive. The rounded halffunnel-shaped hollow may be considered a landform characteristic of niche glacier development.

\section{ConcLusion}

It is the opinion of the author that the majority of niche glaciers in Bünsow Land have developed from the accumulation of snow on the steep valley and fjord sides. Contributory factors to this development are the structure of the area and the climate.

The structural factors are important in that lithological variations give rise to structural 
benches which are near horizontal, and gullies incised into the hillside cause slope variation cutting in a plane at right angles to this. This means that there are many ledges on which snow may accumulate.

The necessary climatic conditions require a period of either fluvial conditions or of a snow cover which melts in the summer and causes the preliminary hillside gullying. This together with the distinctive structural features gives rise to the initial relief in which niche glacier development will take place when winter snow fall exceeds summer ablation. Climatic fluctuations, which lead to the general advance and retreat of glaciers, will cause similar fluctuations in the waxing and waning of the glaciers.

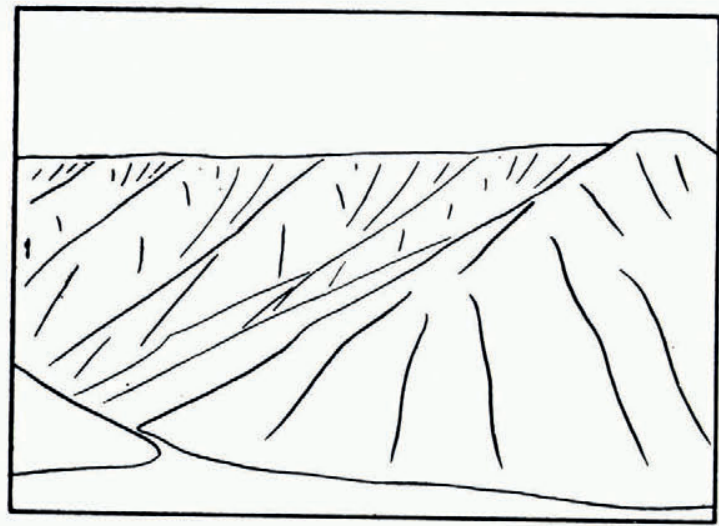

Fig. 5 (a). The characteristic form of niche glacier hollows developed in weak rocks

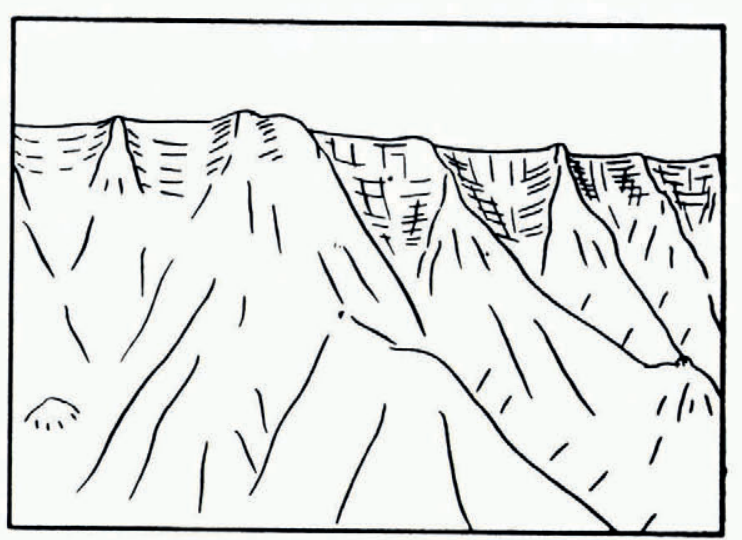

Fig. 5 (b). The characteristic form of niche glacier hollows developed in more resistant rocks

Niche glaciers may thus be considered as glacier types genetically related to corrie glaciers, forming an early stage in corrie development. The glacier, by nivation, modifies the water-worn gully in which it originated to produce a characteristic, rounded, funnel-shaped hollow. The existence of such hollows on steep hillsides and escarpment faces is taken to be indicative of an earlier period of niche glacier activity.

\section{Acknowledgements}

The work described in this paper is based upon that done while the author was a member of the Cambridge Spitsbergen (Physiological) Expedition, 1953. The author acknowledges her indebtedness to Dr. Mary Lobban, leader of the expedition, for the facilities she afforded for these studies, and to all members of the expedition for their co-operation. In particular thanks are due to the author's colleague, Dr. Marjorie Sweeting, for records of field measurements and for helpful discussion. Gifts of equipment from Miss M. F. Pugh and Messrs. Charles H. Pugh, Ltd., Messrs. P. B. Cow and Co., Ltd., Messrs. Windak, Ltd., and Messrs. Mitchells and Butlers, Ltd., are gratefully acknowledged.

This work was made possible by a grant from the Royal Society.

MS. received 25 March $195^{8}$

\section{REFERENCES}

1. Sweeting, M. M., and Groom, G. E. Notes on the glacier fluctuations in Bünsow Land, Central Vestspitsbergen. Journal of Glaciology, Vol. 2, No. 19, i956, p. 640-41.

2. Drygalski, E. von. Spitzbergens Landformen und ihre Vereisung. Abhandlungen der Königlich Bayerischen Akademie der Wissenschaften, München. Mathematisch-Physikalischen Klasse, Bd. 25, No. 7, 1911, p. 18. 
3. Tyrell, G. W. The glaciers of Spitsbergen. Transactions of the Geological Society of Glasgow. Vol. 17, Part I,

1919-22, p. 24.
4. Ahlmann, H. W:son. Glacier morphology. (In Scientific results of the Swedish-Norwegian Arctic Expedition in the summer of 1931. Part VIII.) Geografiska Annaler, Årg. 15, 1933, p. 163.

5. McCabe, L. H. Nivation and corrie erosion in West Spitsbergen. Geographical fournal, Vol. 94, 1939, p. 458.

6. Lewis, W. V. Snow-patch erosion in Iceland. Geographical Journal, Vol. 94, 1939, p. 16o.

7. Wright, C. S., and Priestley, R. E. Glaciology. London, Harrison, 1922, p. I53. (British (Terra Nova) Antarctic Expedition, 1910-13.)

8. Ahlmann, H. W:son. op. cit., 1933 .

9. Ahlmann, H. W:son. Glaciological research on the North Atlantic coasts. London, Royal Geographical Society, 1948, p. 61. (R.G.S. Research Series, No. 1.)

10. Hamberg, A. Om. Kvikkjokksfjällens glacierer. Geologiska Föreningens $i$ Stockholm Förhandlingar, Bd. 18, 1896, p. 624 .

11. Salisbury, R. D. The Greenland Expedition of i895. Journal of Geology, Vol. 3, 1895, p. 888.

12. Lewis, W. V. op. cit., p. I55.

13. McCabe, L. H. op. cit., p. 459 . 


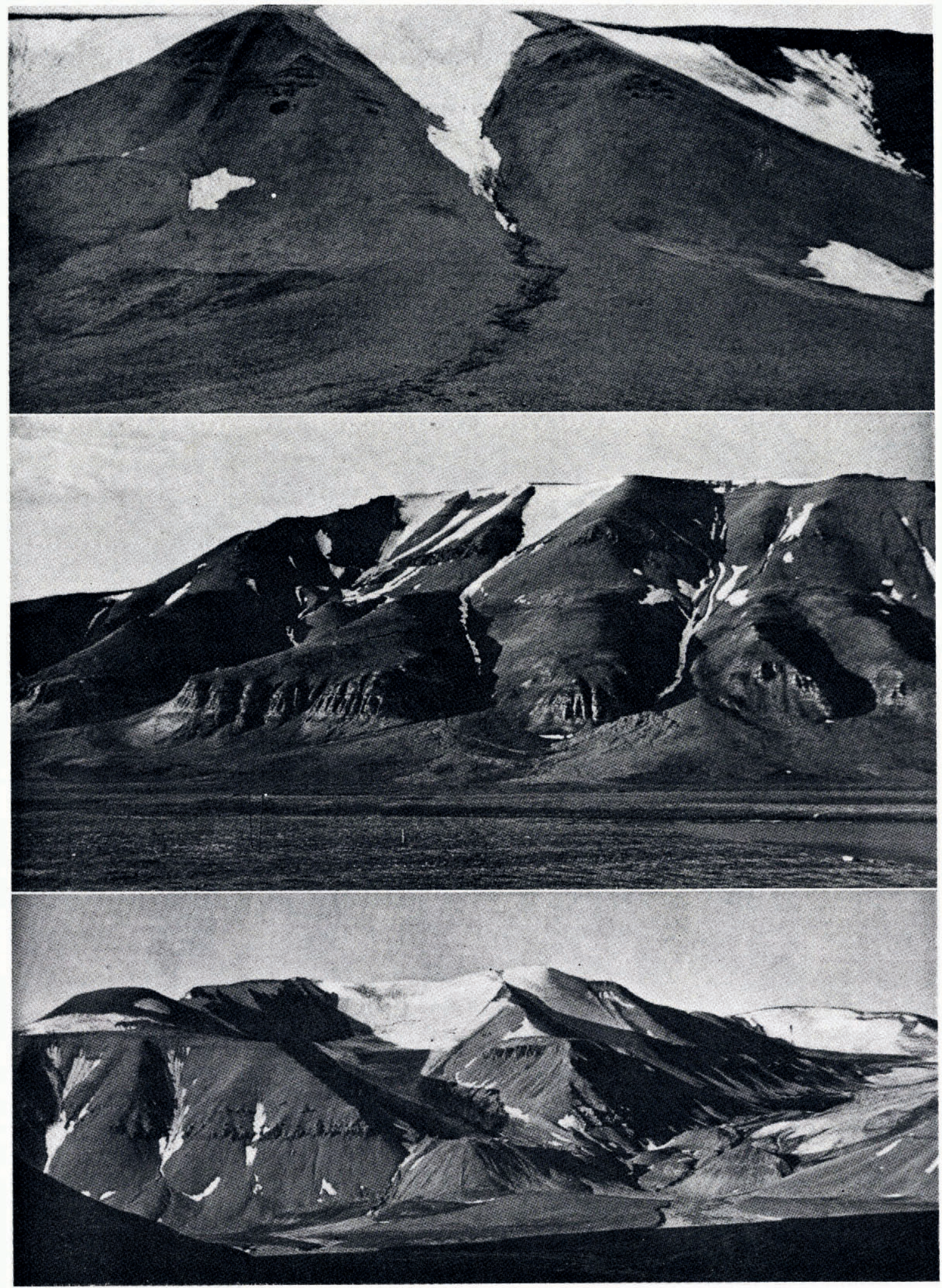

